Article

\title{
Why Did ZIKV Perinatal Outcomes Differ in Distinct Regions of Brazil? An Exploratory Study of Two Cohorts
}

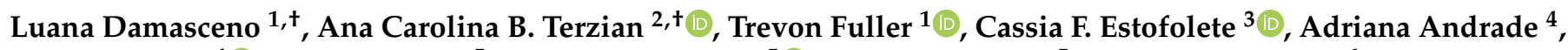 \\ Erna G. Kroon ${ }^{4}{ }^{D}$, Andrea A. Zin ${ }^{5}$, Zilton Vasconcelos ${ }^{5}$ D, Jose P. Pereira Jr. ${ }^{5}$, Márcia C. Castilho ${ }^{6}$, \\ Isa Cristina R. Piaulino ${ }^{7}$, Nikos Vasilakis ${ }^{8}{ }^{D}$, Maria E. Moreira ${ }^{5}$ (D), Karin Nielsen-Saines ${ }^{9}$, \\ Flor E. Martinez Espinosa ${ }^{10,11}$, Maurício L. Nogueira ${ }^{3, *, \ddagger(\mathbb{D})}$ and Patricia Brasil $1, *, \ddagger(\mathbb{D}$
}

Citation: Damasceno, L.; Terzian, A.C.B.; Fuller, T.; Estofolete, C.F.; Andrade, A.; Kroon, E.G.; Zin, A.A.; Vasconcelos, Z.; Pereira, J.P., Jr.; Castilho, M.C.; et al. Why Did ZIKV Perinatal Outcomes Differ in Distinct Regions of Brazil? An Exploratory Study of Two Cohorts. Viruses 2021, 13, 736. https://doi.org/10.3390/ v13050736

Academic Editor:

Luis Martinez-Sobrido

Received: 5 March 2021

Accepted: 7 April 2021

Published: 23 April 2021

Publisher's Note: MDPI stays neutral with regard to jurisdictional claims in published maps and institutional affiliations.

Copyright: (c) 2021 by the authors. Licensee MDPI, Basel, Switzerland. This article is an open access article distributed under the terms and conditions of the Creative Commons Attribution (CC BY) license (https:/ / creativecommons.org/licenses/by/ $4.0 /)$.
1 Acute Febrile Illnesses Laboratory, National Institute of Infectious Diseases, Oswaldo Cruz Foundation (OCRUZ), Rio de Janeiro 21040-900, RJ, Brazil; luana.damasceno@ini.fiocruz.br (L.D.); trevon.fuller@ini.fiocruz.br (T.F.)

2 René Rachou Institute, Oswaldo Cruz Foundation (FIOCRUZ/Minas), Belo Horizonte 30190-002, MG, Brazil; anacarolinaterzian@gmail.com

3 Laboratory of Virology, School of Medicine (FAMERP), São José do Rio Preto 15090-000, SP, Brazil; cassiafestofolete@gmail.com

4 Institute of Biological Sciences, Federal University of Minas Gerais (UFMG), Pampulha-Belo Horizonte 31270-901, MG, Brazil; driquinha.drade@gmail.com (A.A.); kroone@icb.ufmg.br (E.G.K.)

5 Fernandes Figueira Institute, Oswaldo Cruz Foundation (FIOCRUZ), Rio de Janeiro 22250-020, RJ, Brazil; andreazin@iff.fiocruz.br (A.A.Z.); zilton.vasconcelos@iff.fiocruz.br (Z.V.); josepaulo@globo.com (J.P.P.J.); bebethiff@gmail.com (M.E.M.)

6 Department of Virology, Dr. Heitor Vieira Dourado Tropical Medicine Foundation, Manaus 69040-000, AM, Brazil; mcastilho@fmt.am.gov.br

7 Postgraduate Program in Tropical Medicine, Amazonas State University, Manaus 69040-000, AM, Brazil; isa.crissy@gmail.com

8 Department of Pathology, University of Texas Medical Branch, Galveston, TX 77555, USA; nivasila@utmb.edu

9 Department of Pediatrics, David Geffen School of Medicine, University of California,

Los Angeles, CA 90095, USA; knielsen@mednet.ucla.edu

10 Laboratory of Territory, Environment, Health, and Sustainability, Leônidas \& Maria Deane Institute, Oswaldo Cruz Foundation (FIOCRUZ/Amazonia), Manaus 69057-070, AM, Brazil; flor.espinosa@fiocruz.br

11 Department of Malaria, Dr. Heitor Vieira Dourado Tropical Medicine Foundation, Manaus 69040-000, AM, Brazil

* Correspondence: mnogueira@famerp.br.com (M.L.N.); patricia.brasil@ini.fiocruz.br (P.B.)

+ These authors contributed to this work equally.

$\ddagger$ These authors contributed to this work equally.

Abstract: The Zika virus (ZIKV) epidemic in Brazil occurred in regions where dengue viruses (DENV) are historically endemic. We investigated the differences in adverse pregnancy/infant outcomes in two cohorts comprising 114 pregnant women with PCR-confirmed ZIKV infection in Rio de Janeiro, Southeastern Brazil $(n=50)$ and Manaus, in the north region of the country $(n=64)$. Prior exposure to DENV was evaluated through plaque reduction neutralizing antibody assays (PRNT 80) and DENV IgG serologies. Potential associations between pregnancy outcomes and Zika attack rates in the two cities were explored. Overall, 31 women (27\%) had adverse pregnancy/infant outcomes, 27 in Rio $(54 \%)$ and 4 in Manaus (6\%), $p<0.001$. This included 4 pregnancy losses (13\%) and 27 infants with abnormalities at birth (24\%). A total of 93 women (82\%) had evidence of prior DENV exposure, 45 in Rio (90\%) and 48 in Manaus (75\%). Zika attack rates differed; the rate in Rio was 10.28 cases/10,000 and in Manaus, 0.6 cases $/ 10,000, p<0.001$. Only Zika attack rates (Odds Ratio: 17.6, 95\% Confidence Interval 5.6-55.9, $p<0.001$ ) and infection in the first trimester of pregnancy (OR: 4.26, 95\% CI 1.4-12.9, $p=0.011$ ) were associated with adverse pregnancy and infant outcomes. Pre-existing immunity to DENV was not associated with outcomes (normal or abnormal) in patients with ZIKV infection during pregnancy.

Keywords: Zika; pregnancy; obstetrics; arboviruses; dengue 


\section{Introduction}

In recent decades, Brazil has experienced significant flavivirus epidemics, including dengue serotype 1 (DENV-1) in 1998, DENV-3 in 2002, DENV-2 in 2008, DENV-4 in 2010, Zika virus (ZIKV) in 2015-2016, and the reemergence of the Yellow Fever (YF) in 2017 [1,2]. Among these flaviviruses, dengue and Zika had the highest prevalence and the greatest degree of geographic overlap and co-circulation in large cities [2,3].

The morbidity associated with ZIKV infection in pregnancy was first noted when an unprecedented increase in microcephaly was reported in the months following the Zika epidemic, initially in northeastern Brazil, and subsequently spreading to other parts of the country. Not long thereafter, an association between the two epidemics (Zika and microcephaly) was confirmed [4-6]. In November 2015, with thousands of confirmed cases of the disease all over the world, the World Health Organization (WHO) declared an international public health emergency [7-9].

Differing incidence rates for Zika have been reported in regions of Brazil where DENV has historically been endemic or hyperendemic. Thus, most individuals who contracted ZIKV infection likely had prior exposure to at least one DENV serotype [9,10]. In 2016, the Brazilian Ministry of Health estimated that the incidence of Zika in the state of Rio de Janeiro, in the southeastern region of the country, was notably higher than that in the state of Amazonas, in the northern region of Brazil, at 430/100,000 inhabitants and 112/100,000, respectively [11]. Similarly, during the same period, the proportion of cases of microcephaly was also different in these two regions. Between 2015 and 2016, Rio de Janeiro reported 578 cases of microcephaly, while Amazonas reported 25 cases [12].

These distinct scenarios lead to the question of whether an individual's history of DENV exposure could influence the immune response to ZIKV, as these two viruses are antigenically related. While the antigenic structure of ZIKV resembles that of other pathogenic flaviviruses, such as YF, West Nile, and Japanese Encephalitis, ZIKV is most similar to DENV [13]. The two viruses share a conserved surface glycoprotein envelope (E), which is involved in antibody recognition and humoral cross-reactivity between the viruses, producing responses that can either neutralize the virus or have immunopathogenic implications, a phenomenon referred to as antibody-dependent enhancement (ADE) [14-16].

To date, the real influence of preexisting flavivirus immunity in pregnant women with ZIKV infection and adverse outcomes has not been entirely elucidated [10,17] in regions where other flaviviruses co-circulate. The reduction in the incidence of Zika cases since 2016 has made it more difficult to conduct prospective studies that would provide a better understanding of the influence, if any, of prior immunity to DENV on the clinical course of ZIKV infection $[18,19]$. There is evidence from in vitro studies that lower DENV antibody titers are associated with increased viral replication of ZIKV, via the ADE phenomenon, which could potentially result in a higher risk of adverse neonatal outcomes $[15,20]$. On the other hand, high DENV antibody titers could reduce susceptibility to Zika and limit its pathogenicity $[17,21,22]$. It remains unknown whether human populations actually develop this type of cross-immunity and if it affects gestational outcomes [16,23], adverse events, or perinatal transmission $[20,24,25]$.

To investigate the differences in rates of adverse outcomes between these two regions of Brazil we examined the relationship between pre-existing immunity to DENV and abnormalities in symptomatic pregnant women who had RT-PCR-confirmed ZIKV infection in two cohorts from Rio de Janeiro and Manaus. We also looked for a potential association between Zika attack rates during the epidemic and the rate of adverse outcomes in the two cohorts. This question has significant public health implications since most studies investigating these interactions have been in animal models and there is a paucity of human studies addressing this topic. 


\section{Materials and Methods}

\subsection{Clinical Samples}

We analyzed 114 serum specimens collected from pregnant women with acute ZIKV infection between September 2015 and June 2016. Participants were recruited at two sites: the Heitor Vieira Dourado Foundation for Tropical Medicine (FMT-HVD), a referral center for infectious diseases in Manaus $(n=64)$, and the acute febrile illness clinic at the Oswaldo Cruz Foundation (FIOCRUZ) in Rio de Janeiro $(n=50)$. Details of the study design and data collection for these cohorts have been previously described [26-28].

\subsection{Adverse Outcomes}

We considered the presence of the following adverse outcomes or signs: fetal death/stillbirth $(n=4)$; severe microcephaly at birth, defined as three standard deviations below normal head circumference [29] $(n=6)$; clinical neurologic findings (seizures, severe irritability, dysphagia, hypertonia, and hyperreflexia) $(n=10)$; structural brain abnormalities (intracranial subcortical calcifications or ventriculomegaly, based on CT scans) $(n=10)$; congenital contractures, such as clubfoot or arthrogryposis $(n=1)$; smallness for gestational age $(n=4)$; abnormalities based on retinal fundus imaging performed using a fiber optic camera (RetCam) $(n=5)$; hearing deficits diagnosed by brainstem evoked response audiometry (BERA) [30,31] $(n=6)$. Women infected with CMV, toxoplasma, rubella, HSV, and CHIKV during pregnancy were excluded from the study.

\subsection{Laboratory Diagnosis of ZIKV and DENV Infection}

ZIKV infection was confirmed by RT-qPCR of blood and/or urine specimens [32]. Prior immunity to dengue was assessed via serological tests for anti-DENV IgG (with ELISA). In addition, to minimize the effect of potential cross-reactivity between DENV serotypes and ZIKV antibodies, maternal serotype-specific immunity to DENV was evaluated by plaque reduction neutralization tests (PRNT 80) following a standardized protocol, as discussed below.

We defined prior DENV exposure as IgG positive or PRNT 80 positive $(\geq 1: 20)$. The maternal immune response pattern was classified as monotypic (the presence of neutralizing antibodies for a single DENV serotype) or multitypic (defined as the presence of neutralizing antibodies for more than one DENV serotype). Individuals whose serology results for IgG were negative and had no neutralizing antibodies based on the PRNT 80 were classified as having had no prior DENV exposure.

\subsubsection{DENV Virus Stock}

The cell line Ae. albopictus C6/36 was maintained in Leibovitz-15 medium (L-15, Cultilab, Campinas, SP, Brazil) at $28{ }^{\circ} \mathrm{C}$. Growth media were supplemented with $10 \%$ Fetal Bovine Serum (FBS) (Cultilab, Campinas, SP, Brazil; GIBCO, Waltham, MA, USA), $100 \mathrm{U} / \mathrm{mL}$ of penicillin, and $100 \mu \mathrm{g} / \mathrm{mL}$ of streptomycin (GIBCO, Waltham, MA, USA). For the assay, the virus strains used were DENV-1 Mochizuki; DENV-2 NGC; DENV-3 (patient isolate from São Paulo, Brazil); DENV-4 Pe/0081 (patient isolate from Pernambuco, Brazil) and propagated as previously described [33].

The supernatant was harvested 5 days (DENV-2 and 4) or 7 days (DENV-1 and 3) post-infection (dpi) and viral stocks were titered by plaque assay in Vero E6 cells. The virus inoculum was removed following the addition of a semi-solid medium (Minimum Essential Medium (MEM) 1×, 1\% FBS, 1.5\% carboxymethylcellulose). At 7 dpi, the plates were fixed with cold 1:1 methanol/acetone, and the foci were stained immunologically with mouse anti-DENV-2 hyper-immune ascites fluid (MIAF) (1:3000), as previously described [34-36]. The results were expressed as focus-forming units per milliliter (FFU/mL).

\subsubsection{Plaque Reduction Neutralization Tests}

The Vero E6 cell line was maintained in Eagle's Minimum Essential Medium (MEM, Cultilab, Campinas, SP, Brazil) at $37^{\circ} \mathrm{C}$ in a humidified atmosphere containing 5\% CO2. 
Growth media were supplemented with 10\% Fetal Bovine Serum (FBS) (Cultilab, Campinas, SP, Brazil; GIBCO, Waltham, MA, USA), $100 \mathrm{U} / \mathrm{mL}$ of penicillin, and $100 \mu \mathrm{g} / \mathrm{mL}$ of streptomycin (GIBCO, Waltham, MA, USA). Sera samples were inactivated at $56{ }^{\circ} \mathrm{C}$ for $60 \mathrm{~min}$ and assayed to determine the specific neutralization antibody titers, as described previously [34]. Briefly, the PRNT was performed in 24-well plates of Vero cell culture using a fixed virus inoculum (approximately $1000 \mathrm{FFUs}$ ) against varying serum dilutions (1:20-1:640). The plates were then fixed with cold 1:1 methanol/acetone and the foci were stained immunologically with mouse anti-DENV-2 hyper-immune ascites fluid (MIAF) (1:2000), as previously described $[26,27]$. The PRNT titers were scored as reciprocal of the highest dilution of serum that inhibited $80 \%$ of the plaques (PRNT 80). Samples scored as PRNT $80<20$ were considered negative.

\subsubsection{DENV IgG ELISA}

DENV IgG was detected using the Panbio ${ }^{\circledR}$ Dengue IgG Indirect ELISA (Abbott Laboratories, Chicago, IL, USA), according to manufacturer instructions. The assay did not discriminate between DENV serotypes. The plate was read at $450 \mathrm{~nm}$ using a Spectramax Plus ELISA reader (Molecular Devices, LLC, San Jose, CA, USA).

\subsubsection{Avidity Assay}

Serum avidity was measured using a modified protocol adapted from the Panbio ${ }^{\circledR}$ Dengue IgG Indirect ELISA (Abbott Laboratories, Chicago, IL, USA), with guanidine hydrochloride $(\mathrm{GuHCl})$ incubation $[4,5]$. We opted for this kit due to its high sensitivity and specificity for the four DENV serotypes. The optimal concentration to disrupt antigen binding to low avidity antibodies, reducing the antibody binding to $50 \%$, was $2.0 \mathrm{M} \mathrm{GuHCl}$. A control serum with intermediate avidity antibodies was used as a control. Diluted duplicate serum samples were incubated for $30 \mathrm{~min}$ at $37^{\circ} \mathrm{C}$ and washed, and each replicate was incubated with $100 \mu \mathrm{L}$ of $2.0 \mathrm{M} \mathrm{GuHCl}$ or phosphate-buffered saline with $1 \% \mathrm{BSA}$ and $0.2 \%$ Tween 20 (PBS $1 \times$ ). After $15 \mathrm{~min}$ of incubation, at $37^{\circ} \mathrm{C}$, the wells were washed four times and the assay was completed according to the manufacturer's instructions. The plate was read at $450 \mathrm{~nm}$ using a Spectramax Plus ELISA reader (Molecular Devices, LLC, San Jose, CA, USA). PBS $1 \times$ was used in the background control wells and sera from DENV-naïve individuals were used as negative controls. Avidity was calculated as a percentage of the optical density (O.D.) treated with PBS and compared to the O.D. remaining after treatment with the $\mathrm{GuHCl}(\%=(\mathrm{GuHCL}$ O.D./PBS O.D. $) * 100)$, as described previously [37].

\subsection{Attack Rates}

The Zika attack rate in each city was defined as the number of cases reported during the study period divided by the total population size. Zika cases were obtained from the Notifiable Diseases Information System of the Ministry of Health of Brazil (Sistema de Informação de Agravos de Notificação (SINAN). The population of each city was estimated from the national census (IBGE 2016).

\subsection{Statistical Analyses}

The rate of prior DENV exposure among pregnancies with adverse outcomes was compared to the rate in pregnancies with normal outcomes using a Chi-squared test. In addition, we used a regression model to assess the relationship between adverse gestational outcomes and variables, such as the mother's chronological age, gestational age at delivery, and anti-DENV titers by PRNT 80 for the four serotypes. The model also accounted for the nesting of the participants within cities. Failure to address the clustering of the participants by city would lead to an overestimation of the degree of freedom of the data, which could result in erroneous conclusions about the significance of a variable addressing adverse outcomes. To account for such correlation, we utilized a generalized linear mixed model [38], in which the dependent variable was the presence or absence of gestational adverse events. The aforementioned maternal variables were fixed effects, and the city was a random effect 
with the city-specific attack rate as a covariate. The parameters of the model were estimated using the generalized linear mixed-effects model (glmer) procedure in R 3.5.1 software. The significance of the independent variables was assessed via Wald's test.

The study was approved by the local Institutional Review Board (IRB). The authors vouch for the accuracy and completeness of the data and analyses, and for the fidelity of the study to the protocol. Written informed consent was obtained from all participants.

\section{Results}

In the samples selected from the Rio de Janeiro cohort, the rate of adverse outcomes in that group of patients was $54 \%$, while the adverse outcome rate for patients who had specimens in the Manaus cohort was $6 \%$, similar to the results reported for the original cohorts $[26,28]$. The frequency of prior exposure to DENV was $90 \%$ in Rio de Janeiro and $75 \%$ in Manaus (Table 1).

Table 1. Maternal characteristics and infant outcomes stratified by municipality.

\begin{tabular}{|c|c|c|c|c|}
\hline & & Municipality & & $p$ \\
\hline Maternal Characteristics & Total & Rio de Janeiro, RJ $(N=50)$ & Manaus, AM $(N=64)$ & \\
\hline Age & $N(\%)$ & $N(\%)$ & $N(\%)$ & 0.09 \\
\hline$<20$ & $16(14)$ & $5(10)$ & $11(17)$ & \\
\hline $20-29$ & $47(41)$ & $16(32)$ & $31(48)$ & \\
\hline $30-39$ & $45(39)$ & $26(52)$ & $19(30)$ & \\
\hline$>40$ & $6(5)$ & $3(6)$ & $3(5)$ & \\
\hline $\begin{array}{c}\text { Gestational age at the time of } \\
\text { maternal ZIKV infection (weeks) }\end{array}$ & $N(\%)$ & $N(\%)$ & $N(\%)$ & 0.004 \\
\hline$<=26$ & $75(66)$ & $40(80)$ & $35(55)$ & \\
\hline$>=27$ & $35(31)$ & $7(14)$ & $28(44)$ & \\
\hline Missing & $7(6)$ & $3(6)$ & $4(6)$ & \\
\hline DENV IgG & & & & 0.05 \\
\hline Reactive & $93(81)$ & $45(90)$ & $48(75)$ & \\
\hline Non-reactive & $21(18)$ & $5(10)$ & $16(25)$ & \\
\hline Adverse Outcomes & $31(27)$ & $27(54)$ & $4(6)$ & $<0.001$ \\
\hline $\begin{array}{l}\text { Disproportionate } \\
\text { Microcephaly and cerebral } \\
\text { calcifications, irritability, } \\
\text { hypertonicity, abnormal } \\
\text { funduscopic and hearing exam, } \\
\text { and clubfoot or arthrogryposis }\end{array}$ & $6(19)$ & $5(16)$ & $1(3)$ & \\
\hline $\begin{array}{c}\text { Proportional microcephaly, } \\
\text { hypertonicity, or abnormal } \\
\text { neurologic exam }\end{array}$ & $2(6)$ & $2(6)$ & 0 & \\
\hline $\begin{array}{l}\text { Smallness for gestational age (SGA) } \\
\text { and hypotonicity, or hearing deficits } \\
\text { and hypertonicity; structural } \\
\text { abnormality in neuroimaging }\end{array}$ & $4(13)$ & $4(13)$ & 0 & \\
\hline $\begin{array}{l}\text { Abnormal funduscopic exam } \\
\text { and irritability, dysphagia, or } \\
\text { hypertonicity and abnormal reflexes }\end{array}$ & $4(13)$ & $4(13)$ & 0 & \\
\hline $\begin{array}{l}\text { Hearing deficits, hypertonicity, and } \\
\text { abnormal reflexes }\end{array}$ & $3(10)$ & $3(10)$ & 0 & \\
\hline $\begin{array}{l}\text { Hypertonicity and hyperreflexia; } \\
\text { knee fovea, redundant scalp }\end{array}$ & $4(13)$ & $4(13)$ & 0 & \\
\hline Dysphagia and irritability & $1(3)$ & $1(3)$ & 0 & \\
\hline Image structural abnormalities & $3(10)$ & $3(10)$ & 0 & \\
\hline Fetal death/stillbirth & $4(13)$ & $3(10)$ & $1(3)$ & \\
\hline Normal findings & $83(73)$ & $23(46)$ & $60(94)$ & \\
\hline
\end{tabular}


ELISA assays were performed on 114 specimens with the following results: 93 participants $(82 \%)$ had prior DENV exposure (PRNT $\geq 20$ or ELISA-positive) and $21(18 \%)$ had negative DENV antibody results (PRNT $<20$ and ELISA-negative or indeterminate) (Table 2). Of the previously exposed DENV pregnant women (PW), four babies (4.3\%) died before birth, 24 had abnormal findings (25.8\%), and $65(69.9 \%)$ had normal outcomes. Among the $21 \mathrm{PW}$ with no previous exposure to DENV (IgG-negative and PRNT < 1:20), 3 had infants with abnormal outcomes (14.3\%) and 18 infants $(85.7 \%)$ were normal $(p=0.35)$ (Table 2).

Table 2. Maternal characteristics and infant outcomes, stratified by dengue virus (DENV) exposure.

\begin{tabular}{|c|c|c|c|c|}
\hline \multirow[b]{2}{*}{ Maternal Characteristics } & \multicolumn{3}{|c|}{ DENV Exposure } & \multirow[b]{2}{*}{$p$} \\
\hline & Total & Prior DENV Exposure $(N=93)$ & No Prior DENV Exposure $(N=21)$ & \\
\hline Age & $N(\%)$ & $N(\%)$ & $N(\%)$ & 0.179 \\
\hline$<20$ & $16(14.04)$ & $10(10.8)$ & $6(28.6)$ & \\
\hline $20-29$ & $47(41.23)$ & $41(44.1)$ & $6(28.6)$ & \\
\hline $30-39$ & $45(39.47)$ & $37(39.8)$ & $8(38.1)$ & \\
\hline$>40$ & $6(5.26)$ & $5(5.4)$ & $1(4.8)$ & \\
\hline \multirow{5}{*}{$\begin{array}{l}\text { Gestational age at ZIKV } \\
\text { infection with (weeks) } \\
\qquad=26 \\
>=27 \\
\text { Missing }\end{array}$} & $N(\%)$ & $N(\%)$ & $N(\%)$ & 0.603 \\
\hline & 75 (65.79) & $62(66.7)$ & $13(61.9)$ & \\
\hline & $35(30.7)$ & $27(29)$ & $8(38.1)$ & \\
\hline & $8(7.02)$ & $4(4.3)$ & $4(19)$ & \\
\hline & \multicolumn{2}{|r|}{ Municipality } & & 0.052 \\
\hline Rio de Janeiro & $50(43.86)$ & $45(48.4)$ & $5(23.8)$ & \\
\hline Manaus & $64(56.14)$ & $48(51.6)$ & $16(76.2)$ & \\
\hline Infant Outcomes & & & & 0.181 \\
\hline Altered & $31(27.2)$ & $28(30.1)$ & $3(14.2)$ & \\
\hline Non-altered & 83 (70.18) & $65(69.9)$ & $18(85.8)$ & \\
\hline
\end{tabular}

Of the 114 samples tested by PRNT, the most prevalent serotypes were DENV-1 (68.4\%), DENV-2 (59.7\%), and DENV-4 (42.98\%), and the least prevalent serotype was DENV-3 (4.4\%). Multitypic DENV exposure had occurred in $89 \%(n=57)$ of the participants, based on the neutralization of more than one DENV serotype (Figure 1).

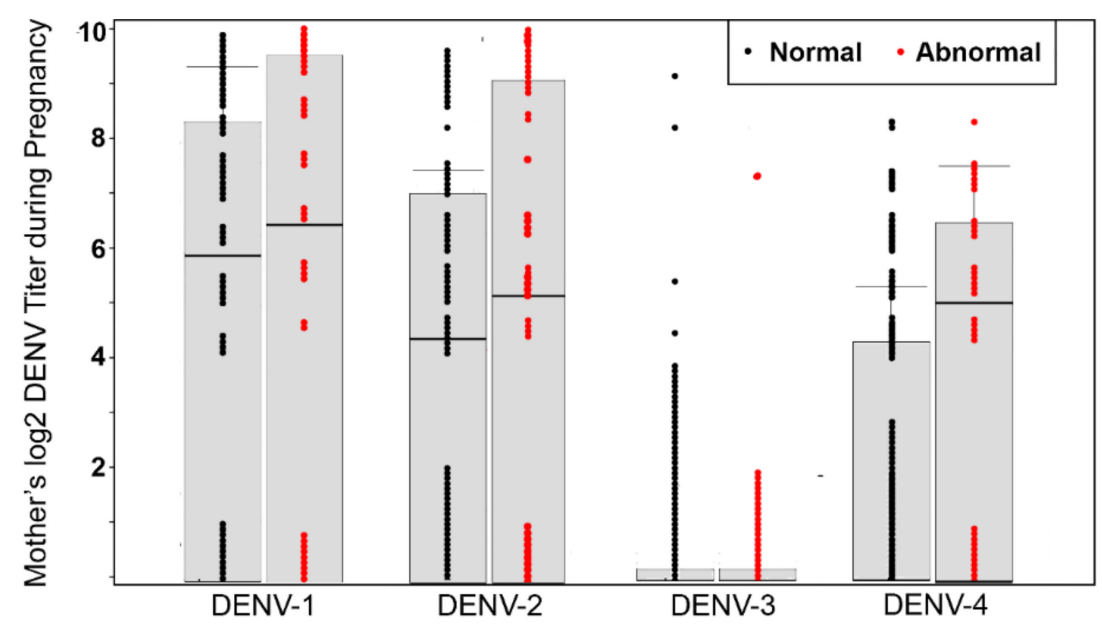

Figure 1. Effect of maternal DENV titer during pregnancy on adverse outcomes $(N=114)$. The rate of abnormal births in mothers with DENV-neutralizing antibodies was different than that of mothers lacking such antibodies. 
The median $\log 2$ titer for specific serotypes in pregnancies with abnormal outcomes was 6.32 DENV-1 (95\% CI 0-9.32), 5.32 DENV-2 (95\% CI 0-9.32), 0 DENV-3 (CI 0-0), and 4.91 DENV-4 (CI 0-6.32). For normal outcomes, the median log2 titer for specific serotypes was 5.9 DENV-1 (95\% CI 0-8.3), 4.3 DENV-2 (95\%CI 0-7.1), 0 DENV-3 (CI 0-0), and 0 DENV-4 (CI 0-4.3) (Table 3 and Figure 1). Fully, 70\% of pregnancies with adverse outcomes had neutralizing antibodies against at least two DENV serotypes. However, the association between monotypic or heterotypic DENV infection and adverse gestational outcomes was not statistically significant (Table 4).

Table 3. Maternal characteristics and neonatal outcomes.

\begin{tabular}{|c|c|c|c|c|}
\hline \multirow[b]{2}{*}{ Maternal Characteristics } & \multicolumn{3}{|c|}{ Infant Outcomes } & \multirow[b]{2}{*}{$p$} \\
\hline & Total & $\begin{array}{l}\text { Normal } \\
\text { Findings }\end{array}$ & $\begin{array}{l}\text { Abnormal } \\
\text { Findings }\end{array}$ & \\
\hline Age & $N(\%)$ & $N(\%)$ & $N(\%)$ & 0.34 \\
\hline$<20$ & $16(14)$ & $10(16)$ & $6(12)$ & \\
\hline $20-29$ & $44(38)$ & $28(44)$ & $16(31)$ & \\
\hline $30-39$ & $48(42)$ & $22(35)$ & $26(51)$ & \\
\hline$>40$ & $6(5)$ & $3(5)$ & $3(6)$ & \\
\hline $\begin{array}{l}\text { Gestational age at the } \\
\text { time of maternal ZIKV } \\
\text { infection(weeks) }\end{array}$ & $N(\%)$ & $N(\%)$ & $N(\%)$ & $<0.001$ \\
\hline$<=26$ & $75(66)$ & $53(66)$ & $22(65)$ & \\
\hline$>=27$ & $35(31)$ & $27(34)$ & $8(24)$ & \\
\hline Missing & $4(4)$ & 0 & $4(12)$ & \\
\hline \multicolumn{4}{|c|}{ Log2 DENV PRNT 80 ( $N=114$, median, IQR) } & 0.474 \\
\hline DENV-1 & $6.3(0-8.1)$ & $5.9(0-8.3)$ & $6.3(0-9.3)$ & \\
\hline DENV-2 & $4.4(0-7.3)$ & $4.3(0-7.1)$ & $5.3(0-9.3)$ & \\
\hline DENV-3 & 0 & 0 & 0 & \\
\hline DENV-4 & $0(0-5.4)$ & $0(0-4.3)$ & $4.9(0-6.3)$ & \\
\hline Municipality & $N(\%)$ & $N(\%)$ & $N(\%)$ & $<0.001$ \\
\hline Rio de Janeiro & $50(43.9)$ & $23(28.7)$ & $27(79.4)$ & \\
\hline Manaus & $64(56.1)$ & $57(71.3)$ & $7(20.6)$ & \\
\hline
\end{tabular}

Table 4. Multivariate logistic regression of predictors of infant abnormalities at birth $(N=114)$.

\begin{tabular}{ccc}
\hline Variables & Odds Ratio (95\% CI) & $p$ \\
\hline $\begin{array}{c}\text { Municipal-scale variable } \\
\text { Attack rate } \\
\text { Rio vs. Manaus }\end{array}$ & $17.6(5.55-55.88)$ & $<0.001$ \\
\hline \multicolumn{2}{c}{ Maternal categorical variables } \\
\hline First trimester ZIKV infection & $4.26(1.4-12.9)$ & 0.011 \\
Monotypic DENV infection vs. no DENV infection & $0.78(0.18-3.31)$ & 0.73 \\
Heterotypic vs. monotypic DENV infection & $0.466(0.154-1.413)$ & 0.18 \\
\hline \multicolumn{2}{c}{ Maternal continuous variables } \\
\hline Maternal age & $1.0(0.99-1)$ & 0.59 \\
DENV-1 titer & $0.99(0.99-1)$ & 0.198 \\
DENV-2 titer & $0.99(0.99-1)$ & 0.846 \\
DENV-3 titer & $0.99(0.98-1.0)$ & 0.32 \\
DENV-4 titer & $1(0.99-1.01)$ & 0.7 \\
Test of avidity & $0.99(0.96-1.02)$ & 0.523 \\
\hline
\end{tabular}

The avidity assay was performed on 96 samples. There was no difference in DENV avidity between mothers with adverse gestational outcomes and those with normal outcomes (Supplemental Figures S1 and S2). No effect of maternal DENV titer during preg- 
nancy and abnormal outcomes were observed. However, there was a significant association between the trimester of infection $(p=0.027)$ and the Zika attack rate in Rio de Janeiro $(10.28$ cases $/ 10,000)$ and in Manaus $(0.6$ cases $/ 10,000)(p<0.001)$ (Table 4$)$. In the regression model, the coefficient of the attack rate was a positive number, indicating that the probability of an adverse outcome increased with the increasing incidence of ZIKV infection (Table 4 and Figure 2).

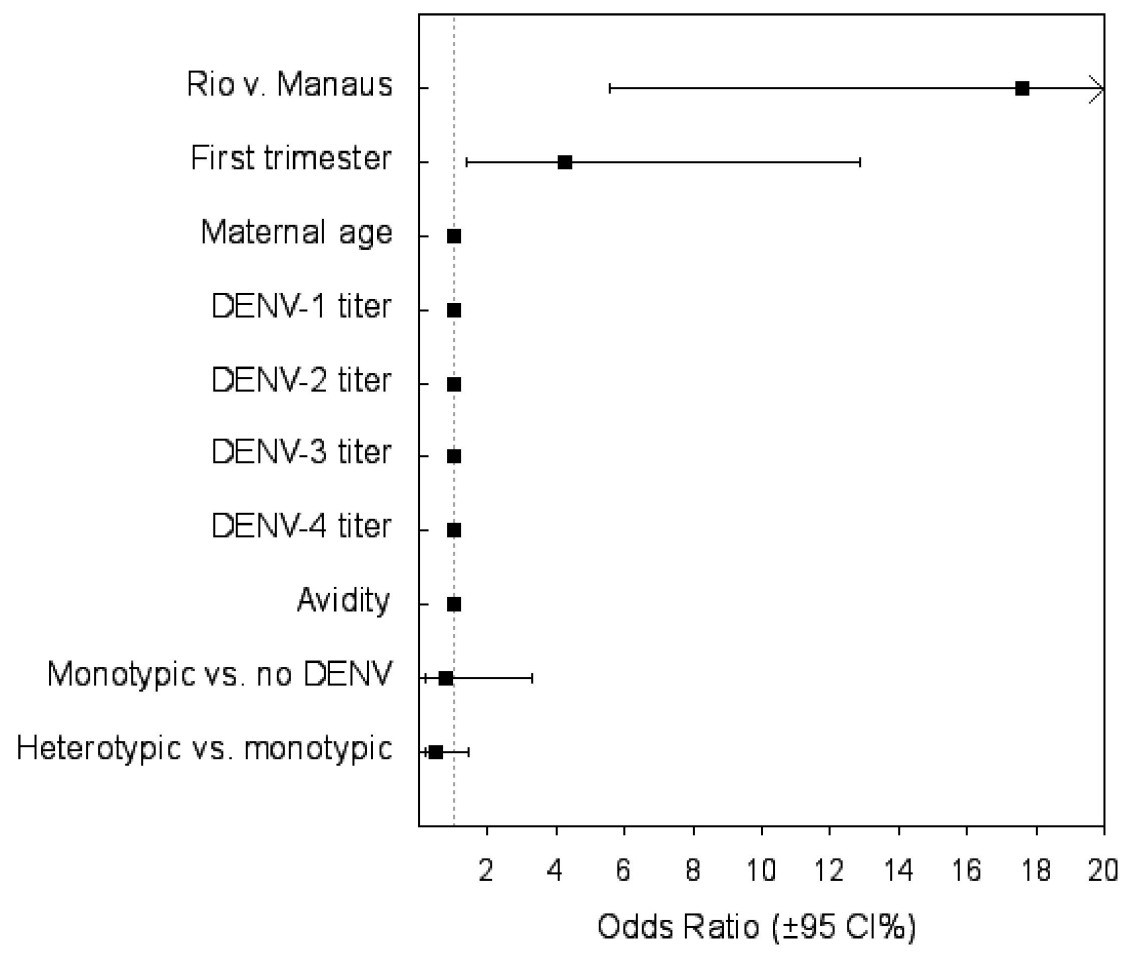

Figure 2. Risk factors for infant abnormalities at delivery $(N=114)$.

\section{Discussion}

In the present study, only the Zika attack rate and the time of infection during pregnancy were significantly associated with the risk of adverse outcomes. Women infected in the first trimester were more likely to deliver infants with abnormalities, adding to the growing evidence that ZIKV infection early in pregnancy has a generalizable association with microcephaly [29]. Our findings regarding Zika attack rates support previous studies that demonstrated geographic differences in Zika incidence, such as the disproportionately high rates of Zika and microcephaly in northeastern Brazil [39,40] and a lower rate of microcephaly identified in Manaus.

However, these results should be interpreted with caution. The real proportion of ZIKV infection in the population in many regions of Brazil may not be represented because of missing data in the notification system SINAN, prior to the establishment of a nationwide ZIKV surveillance system $[19,41]$.

A theory has also been mooted that pre-existing immunity to co-circulating flaviviruses from prior natural infection (e.g., dengue, YF) or from vaccination to YF may influence ZIKV disease severity and pregnancy outcomes [42]. As YF vaccination is compulsory in the Amazon region, it could protect the population from ZIKV infection, as demonstrated in a Brazilian study based on population spatial-temporal clusters between YF vaccination coverage and ZIKV-associated microcephaly [43]. The offspring of pregnant women in regions with high YF vaccination coverage seemed to experience less risk of microcephaly and overall congenital Zika syndrome. This association suggests that flavivirus antibodies could be protective against severe manifestations of ZIKV infection, including during pregnancy [43]. This observation could also be due to a lower Zika 
attack rate conferred by YF immunization, translating into a smaller number of cases of microcephaly, which generally occur in 3 to $5 \%$ of infants exposed to ZIKV in utero [26,44].

We did not detect any temporal associations between prior DENV infection and adverse pregnancy outcomes, as measured by the IgG ELISA test avidity in either Rio de Janeiro or Manaus (Table 4). This is distinct from a recent ecological study that demonstrated that the risk of microcephaly was lower in municipalities that experienced a DENV epidemic up to six years prior to the introduction of ZIKV into the community [18].

In our results, pre-existing immunity to DENV, neutralizing antibody (NAbs) titers, and multitypic DENV immunity during pregnancy neither conferred protection nor increased the risk of adverse outcomes. These are compatible with previous studies in non-human primates [45] but unlike prior studies in humans [21,46]. This difference may be attributable to differences in the study design, the definition of ZIKV infection, and the ascertainment of outcomes. Furthermore, unlike the present analysis, previous studies did not utilize sera from ZIKV-infected participants diagnosed via RT-PCR.

The strengths of our study include a careful classification of infant outcomes, made possible through detailed assessments at birth by a multidisciplinary team. This type of ascertainment is not possible in secondary analyses performed through routinely collected surveillance data., In addition, the use of a highly sensitive and specific PRNT assay to characterize pre-existing DENV immunity and the use of sera collected during the acute phase of ZIKV RT-PCR-confirmed infection lends credibility to our results. Our study design also allowed us to determine the trimester of maternal ZIKV infection and to prospectively evaluate fetal losses and abnormalities before birth.

Our main limitations are the modest sample size and convenience sample selection. For this reason, the extent to which our findings can be generalized to other populations remains unknown. Our population consisted of women with symptomatic ZIKV infection, which is what allowed us to determine the timing of infection. Furthermore, since we classified neonates as normal or abnormal at delivery, we may have missed adverse outcomes that emerge later in development [44].

In summary, in this study, women with prior DENV exposure who were infected with ZIKV during pregnancy did not experience a higher rate of adverse outcomes at delivery in these two regions. However, disentangling the effects of these infections on gestation remains challenging due to the similar clinical presentations of DENV and ZIKV illnesses and the waning of DENV antibody titers over time.

Supplementary Materials: The following are available online at https:/ /www.mdpi.com/article/10 $.3390 / v 13050736 / \mathrm{s} 1$, Figure S1: DENV antibody avidity, stratified by normal and adverse gestational outcomes. Figure S2: DENV antibody avidity in pregnant women infected with ZIKV, stratified by normal or adverse gestational outcomes.

Author Contributions: Conceptualization, P.B., F.E.M.E. and M.L.N.; methodology, A.C.B.T., L.D., C.F.E., A.A., E.G.K., A.A.Z., Z.V., J.P.P.J., M.C.C., I.C.R.P. and N.V.; formal analysis, T.F.; investigation, L.D., A.C.B.T.; resources, P.B., F.E.M.E. and M.L.N.; data curation, L.D. and A.C.B.T.; writing-original draft preparation, L.D., A.C.B.T. and T.F.; writing-review and editing, P.B., F.E.M.E., M.L.N., K.N.-S. and M.E.M.; supervision, P.B., F.E.M.E. and M.L.N.; project administration, P.B., F.E.M.E. and M.L.N. All authors have read and agreed to the published version of the manuscript.

Funding: This work was supported by the São Paulo Research Foundation (FAPESP) (Grants 2013/21719-3 and 2016/15021-1 to M.L.N. and 2015/12295-0 to ACBT), the FAPESP Zika Network, and the Brazilian National Institutes for Science and Technology for Dengue Studies (INCT-Dengue). M.L.N. is a Brazilian National Council for Scientific and Technological Development (CNPq) Research Fellow. Additional support was provided by the Departamento de Ciência e Tecnologia (DECIT) do Ministério da Saúde do Brasil (25000.072811/2016-17); Coordenacao de Aperfeicoamento de Pessoal de Nivel Superior (CAPES) (88887.116627/2016-01); Brazilian National Council for Scientific and Technological Development (CNPq) (441098/2016-9); Fundação Carlos Chagas Filho de Amparo à Pesquisa do Estado do Rio de Janeiro (FAPERJ) (E_18/2015TXB); the National Institute of Allergy and Infectious Diseases of the National Institutes of Health (NIH) (AI140718); the National Eye Institute of the NIH (AI129847); Fondation Christophe and Rodolphe Mérieux; Print Fiocruz-Capes. 
Institutional Review Board Statement: The study was conducted according to the guidelines of the Declaration of Helsinki and approved by the Institutional Review Board of the Oswaldo Cruz Foundation (88551218.6.0000.5262) and the Heitor Vieira Dourado Tropical Medicine Foundation (60168216.2.0000.0005).

Informed Consent Statement: Informed consent was obtained from all subjects involved in the study.

Data Availability Statement: De-identified data are available from the authors upon request.

Conflicts of Interest: The authors declare no conflict of interest. The funders had no role in the design of the study; in the collection, analyses, or interpretation of data; in the writing of the manuscript, or in the decision to publish the results.

\section{References}

1. MS. Boletim Epidemiológico Secretaria de Vigilância em Saúde. Vol 46. n 42, 2015a. Available online: http://portalarquivos. saude.gov.br/images/pdf/2015/dezembro/11/svs-be-2015-047-dengue-se47-final.pdf (accessed on 7 October 2020). (In Portugese)

2. Microcefalias. Centro de Operações de Emergências em Saúde Pública sobre Microcefalias.-Informe epidemiológico $n^{\circ}$ 02/2015Semana Epidemiológica 47 de 2015. Brasil, Ministério da Saúde. Available online: http:/ / portalsaude.saude.gov.br/images/ pdf/2015/novembro/30/COES-Microcefalias---Informe-Epidemiologico---SE-47---30nov2015.pdf (accessed on 7 October 2020). (In Portugese)

3. França, G.V.; Schuler-Faccini, L.; Oliveira, W.K.; Henriques, C.M.; Carmo, E.H.; Pedi, V.D.; Nunes, M.L.; Castro, M.C.; Serruya, S.; Silveira, M.F.; et al. Congenital Zika virus syndrome in Brazil: A case series of the first 1501 livebirths with complete investigation. Lancet 2016, 388, 891-897. [CrossRef]

4. Brito, C. Zika Virus: A New Chapter in the History of Medicine. Acta Med. Port. 2015, 28, 679-680. [CrossRef] [PubMed]

5. Albuquerque, M.F.P.M.; Souza, W.V.; Araújo, T.V.B.; Braga, M.C.; Miranda Filho, D.B.; Ximenes, R.A.A.; de Melo Filho, D.A.; Brito, C.A.A.; Valongueiro, S.; Melo, A.P.L.; et al. The microcephaly epidemic and Zika virus: Building knowledge in epidemiology. Cad. Saude Publica 2018, 34, e00069018. [PubMed]

6. Brasil, P.; Calvet, G.A.; Siqueira, A.M.; Wakimoto, M.; de Sequeira, P.C.; Nobre, A.; Quintana Mde, S.; Mendonça, M.C.; Lupi, O.; de Souza, R.V.; et al. Zika Virus Outbreak in Rio de Janeiro, Brazil: Clinical Characterization, Epidemiological and Virological Aspects. PLoS Negl. Trop. Dis. 2016, 10, e0004636. [CrossRef]

7. OMS. Epidemiological Alert-Zika Virus Infection. Available online: https://www.paho.org/hq/dmdocuments/2015/2015-dec1-cha-epi-alert-zika-neuro-syndrom (accessed on 9 November 2020).

8. OMS. Epidemiological Alert-Increase of Microcephaly in the Northeast of Brazil. Available online: https://www.paho.org/hq/ dmdocuments/2015/2015-nov-17-cha-microcephaly-epi-alert.pdf (accessed on 9 November 2020).

9. Gulland, A. Zika virus is a global public health emergency, declares WHO. BMJ 2016, 352, i657. [CrossRef]

10. Rodriguez-Barraquer, I.; Costa, F.; Nascimento, E.J.M.; Nery, N.; Castanha, P.M.S.; Sacramento, G.A.; Cruz, J.; Carvalho, M.; De Olivera, D.; Hagan, J.E.; et al. Impact of preexisting dengue immunity on Zika virus emergence in a dengue endemic region. Science 2019, 363, 607-610. [CrossRef]

11. MS, Monitoramento dos casos de Dengue, Febre de Chikungunya e Febre Pelo Vírus Zika até a Semana Epidemiológica 52. 2016. Available online: https://www.saude.gov.br/images/pdf/2017/abril/06/2017-002-Monitoramento-dos-casos-de-dengue-febre-de-chikungunya-e-febre-pelo-v--rus-Zika-ate-a-Semana-Epidemiologica-52--2016.pdf (accessed on 22 February 2020).

12. MS. Ministério da Saúde Confirma 1.709 Casos de Microcefalia. Available online: https://www.saude.gov.br//saude/pt-br/ assuntos/noticias/ministerio-da-saude-confirma-1-709-casos-de-microcefalia (accessed on 22 February 2021).

13. Heinz, F.X.; Stiasny, K. The Antigenic Structure of Zika Virus and Its Relation to Other Flaviviruses: Implications for Infection and Immunoprophylaxis. Microbiol. Mol. Biol. Rev. 2017, 81, e00055-16. [CrossRef]

14. Priyamvada, L.; Hudson, W.; Ahmed, R.; Wrammert, J. Humoral cross-reactivity between Zika and dengue viruses: Implications for protection and pathology. Emerg. Microbes Infect. 2017, 6, e33. [CrossRef]

15. Bardina, S.V.; Bunduc, P.; Tripathi, S.; Duehr, J.; Frere, J.J.; Brown, J.A.; Nachbagauer, R.; Foster, G.A.; Krysztof, D.; Tortorella, D.; et al. Enhancement of Zika virus pathogenesis by preexisting antiflavivirus immunity. Science 2017, 356, 175-180. [CrossRef]

16. Collins, M.H.; McGowan, E.; Jadi, R.; Young, E.; Lopez, C.A.; Baric, R.S.; Lazear, H.M.; de Silva, A.M. Lack of Durable Cross-Neutralizing Antibodies Against Zika Virus from Dengue Virus Infection. Emerg. Infect. Dis. 2017, 23, 773-781. [CrossRef]

17. Montoya, M.; Collins, M.; Dejnirattisai, W.; Katzelnick, L.C.; Puerta-Guardo, H.; Jadi, R.; Schildhauer, S.; Supasa, P.; Vasanawathana, S.; Malasit, P.; et al. Longitudinal Analysis of Antibody Cross-neutralization Following Zika Virus and Dengue Virus Infection in Asia and the Americas. J. Infect. Dis. 2018, 218, 536-545. [CrossRef] [PubMed]

18. Carvalho, M.S.; Freitas, L.P.; Cruz, O.G.; Brasil, P.; Bastos, L.S. Association of past dengue fever epidemics with the risk of Zika microcephaly at the population level in Brazil. Sci. Rep. 2020, 10, 1752. [CrossRef] 
19. Brady, O.J.; Osgood-Zimmerman, A.; Kassebaum, N.J.; Ray, S.E.; de Araújo, V.E.M.; da Nóbrega, A.A.; Frutuoso, L.C.V.; Lecca, R.C.R.; Stevens, A.; Zoca de Oliveira, B.; et al. The association between Zika virus infection and microcephaly in Brazil 2015-2017: An observational analysis of over 4 million births. PLoS Med. 2019, 16, e1002755. [CrossRef] [PubMed]

20. Katzelnick, L.C.; Gresh, L.; Halloran, M.E.; Mercado, J.C.; Kuan, G.; Gordon, A.; Balmaseda, A.; Harris, E. Antibody-dependent enhancement of severe dengue disease in humans. Science 2017, 358, 929-932. [CrossRef] [PubMed]

21. Regla-Nava, J.A.; Elong Ngono, A.; Viramontes, K.M.; Huynh, A.T.; Wang, Y.T.; Nguyen, A.T.; Salgado, R.; Mamidi, A.; Kim, K.; Diamond, M.S.; et al. Cross-reactive Dengue virus-specific CD8 ${ }^{+} \mathrm{T}$ cells protect against Zika virus during pregnancy. Nat. Commun. 2018, 9, 3042. [CrossRef]

22. Moreira-Soto, A.; Cabral, R.; Pedroso, C.; Eschbach-Bludau, M.; Rockstroh, A.; Vargas, L.A.; Postigo-Hidalgo, I.; Luz, E.; Sampaio, G.S.; Drosten, C.; et al. Exhaustive TORCH Pathogen Diagnostics Corroborate Zika Virus Etiology of Congenital Malformations in Northeastern Brazil. $m$ Sphere 2018, 3, e00278-18. [CrossRef]

23. Halstead, S.B. Biologic Evidence Required for Zika Disease Enhancement by Dengue Antibodies. Emerg. Infect. Dis. 2017, 23, 569-573. [CrossRef]

24. Khandia, R.; Munjal, A.; Dhama, K.; Karthik, K.; Tiwari, R.; Malik, Y.S.; Singh, R.K.; Chaicumpa, W. Modulation of Dengue/Zika Virus Pathogenicity by Antibody-Dependent Enhancement and Strategies to Protect Against Enhancement in Zika Virus Infection. Front. Immunol. 2018, 9, 597. [CrossRef]

25. Castanha, P.M.S.; Nascimento, E.J.M.; Braga, C.; Cordeiro, M.T.; de Carvalho, O.V.; de Mendonça, L.R.; Azevedo, E.A.N.; França, R.F.O.; Dhalia, R.; Marques, E.T.A. Dengue Virus-Specific Antibodies Enhance Brazilian Zika Virus Infection. J. Infect. Dis. 2017, 215, 781-785. [CrossRef]

26. Brasil, P.; Pereira, J.P.; Moreira, M.E.; Ribeiro Nogueira, R.M.; Damasceno, L.; Wakimoto, M.; Rabello, R.S.; Valderramos, S.G.; Halai, U.A.; Salles, T.S.; et al. Zika Virus Infection in Pregnant Women in Rio de Janeiro. N. Engl. J. Med. 2016, 375, $2321-2334$. [CrossRef]

27. Nogueira, M.L.; Nery Júnior, N.R.R.; Estofolete, C.F.; Bernardes Terzian, A.C.; Guimarães, G.F.; Zini, N.; Alves da Silva, R.; Dutra Silva, G.C.; Junqueira Franco, L.C.; Rahal, P.; et al. Adverse birth outcomes associated with Zika virus exposure during pregnancy in São José do Rio Preto, Brazil. Clin. Microbiol. Infect. 2018, 24, 646-652. [CrossRef]

28. Redivo, E.F.; Bôtto Menezes, C.; da Costa Castilho, M.; Brock, M.; da Silva Magno, E.; Gomes Saraiva, M.D.G.; Alvarez Fernandes, S.S.; Costa Antony de Andrade, A.B.; Costa Alecrim, M.D.G.; Martinez-Espinosa, F.E. Zika Virus Infection in a Cohort of Pregnant Women with Exanthematic Disease in Manaus, Brazilian Amazon. Viruses 2020, 12, 1362. [CrossRef] [PubMed]

29. Villar, J.; Cheikh Ismail, L.; Victora, C.G.; Ohuma, E.O.; Bertino, E.; Altman, D.G.; Lambert, A.; Papageorghiou, A.T.; Carvalho, M.; Jaffer, Y.A.; et al. International Fetal and Newborn Growth Consortium for the 21st Century (INTERGROWTH-21st). International standards for newborn weight, length, and head circumference by gestational age and sex: The Newborn Cross-Sectional Study of the INTERGROWTH-21st Project. Lancet 2014, 384, 857-868. [PubMed]

30. Moore, C.A.; Staples, J.E.; Dobyns, W.B.; Pessoa, A.; Ventura, C.V.; Fonseca, E.B.; Ribeiro, E.M.; Ventura, L.O.; Neto, N.N.; Arena, J.F.; et al. Characterizing the Pattern of Anomalies in Congenital Zika Syndrome for Pediatric Clinicians. JAMA Pediatr. 2017, 171, 288-295. [CrossRef] [PubMed]

31. Rasmussen, S.A.; Jamieson, D.J.; Honein, M.A.; Petersen, L.R. Zika Virus and Birth Defects-Reviewing the Evidence for Causality. N. Engl. J. Med. 2016, 374, 1981-1987. [CrossRef]

32. Lanciotti, R.S.; Kosoy, O.L.; Laven, J.J.; Velez, J.O.; Lambert, A.J.; Johnson, A.J.; Stanfield, S.M.; Duffy, M.R. Genetic and serologic properties of Zika virus associated with an epidemic, Yap State, Micronesia, 2007. Emerg. Infect. Dis. 2008, 14, 1232-1239. [CrossRef]

33. Figueiredo, L.T. Uso de células de Aedes albopictus C6/36 na propagação e classificação de arbovírus das famílias Togaviridae, Flaviviridae, Bunyaviridae e Rhabdoviridae [The use of Aedes albopictus C6/36 cells in the propagation and classification of arbovirus of the Togaviridae, Flaviviridae, Bunyaviridae and Rhabdoviridae families]. Rev. Soc. Bras. Med. Trop. 1990, $23,13-18$.

34. Vasilakis, N.; Durbin, A.P.; da Rosa, A.P.; Munoz-Jordan, J.L.; Tesh, R.B.; Weaver, S.C. Antigenic relationships between sylvatic and endemic dengue viruses. Am. J. Trop. Med. Hyg. 2008, 79, 128-132. [CrossRef]

35. Roehrig, J.T.; Hombach, J.; Barrett, A.D. Guidelines for Plaque-Reduction Neutralization Testing of Human Antibodies to Dengue Viruses. Viral Immunol. 2008, 21, 123-132. [CrossRef]

36. Vasilakis, N.; Shell, E.J.; Fokam, E.B.; Mason, P.W.; Hanley, K.A.; Estes, D.M.; Weaver, S.C. Potential of ancestral sylvatic dengue-2 viruses to re-emerge. Virology 2007, 358, 402-412. [CrossRef]

37. Polanec, J.; Seppälä, I.; Rousseau, S.; Hedman, K. Evaluation of protein-denaturing immunoassays for avidity of immunoglobulin G to rubella virus. J. Clin. Lab. Anal. 1994, 8, 16-21. [CrossRef]

38. Breslow, N.E.; Clayton, D.G. Approximate Inference in Generalized Linear Mixed Models. J. Am. Stat. Assoc. 1993, $88,9-25$.

39. Villela, D.A.M.; Bastos, L.S.; De Carvalho, L.M.; Cruz, O.G.; Gomes, M.F.C.; Durovni, B.; Lemos, M.C.; Saraceni, V.; Coelho, F.C.; Codeço, C.T. Zika in Rio de Janeiro: Assessment of basic reproduction number and comparison with dengue outbreaks. Epidemiol. Infect. 2017, 145, 1649-1657. [CrossRef] [PubMed]

40. Jaenisch, T.; Rosenberger, K.D.; Brito, C.; Brady, O.; Brasil, P.; Marques, E.T. Risk of microcephaly after Zika virus infection in Brazil, 2015 to 2016. Bull. World Health Organ. 2017, 95, 191-198. [CrossRef] 
41. Braga, J.U.; Bressan, C.; Dalvi, A.P.R.; Calvet, G.A.; Daumas, R.P.; Rodrigues, N.; Wakimoto, M.; Nogueira, R.M.R.; Nielsen-Saines, K.; Brito, C.; et al. Accuracy of Zika virus disease case definition during simultaneous Dengue and Chikungunya epidemics. PLoS ONE 2017, 12, e0179725. [CrossRef] [PubMed]

42. Mansfield, K.L.; Horton, D.L.; Johnson, N.; Li, L.; Barrett, A.D.T.; Smith, D.J.; Galbraith, S.E.; Solomon, T.; Fooks, A.R. Flavivirusinduced antibody cross-reactivity. J. Gen. Virol. 2011, 92, 2821-2829. [CrossRef]

43. De Góes Cavalcanti, L.P.; Tauil, P.L.; Alencar, C.H.; Oliveira, W.; Teixeira, M.M.; Heukelbach, J. Zika virus infection, associated microcephaly, and low yellow fever vaccination coverage in Brazil: Is there any causal link? J. Infect. Dev. Ctries. 2016, 10, 563-566. [CrossRef] [PubMed]

44. Nielsen-Saines, K.; Brasil, P.; Kerin, T.; Vasconcelos, Z.; Gabaglia, C.R.; Damasceno, L.; Pone, M.; Abreu de Carvalho, L.M.; Pone, S.M.; Zin, A.A.; et al. Delayed childhood neurodevelopment and neurosensory alterations in the second year of life in a prospective cohort of ZIKV-exposed children. Nat. Med. 2019, 25, 1213-1217. [CrossRef]

45. McCracken, M.K.; Gromowski, G.D.; Friberg, H.L.; Lin, X.; Abbink, P.; De La Barrera, R.; Eckles, K.H.; Garver, L.S.; Boyd, M.; Jetton, D.; et al. Impact of prior flavivirus immunity on Zika virus infection in rhesus macaques. PLoS Pathog. 2017, 13, e1006487. [CrossRef]

46. Pedroso, C.; Fischer, C.; Feldmann, M.; Sarno, M.; Luz, E.; Moreira-Soto, A.; Cabral, R.; Netto, E.M.; Brites, C.; Kümmerer, B.M.; et al. Cross-Protection of Dengue Virus Infection against Congenital Zika Syndrome, Northeastern Brazil. Emerg. Infect. Dis. 2019, 25, 1485-1493. [CrossRef] 